\title{
Corrosion Resistance Investigation of Titanium Alloy as Tissue Engineered Bone Implant
}

\author{
Shengxin Zhou ${ }^{1 \#}$, Jin Wang ${ }^{2 \#}$ and Pan Cai ${ }^{3 *}$ \\ ${ }^{1}$ The First Department of Orthopaedics, Pingyi County People's Hospital of Shandong, No.7 Jinhua \\ Rd, Economic Development Area, Pingyi, Shandong, P.R. China \\ ${ }^{2}$ Department of Joint orthopedic surgery, The First People' s Hospital of Hefei, Anhui, P.R. China. \\ ${ }^{3}$ Department of Orthopedics, Shanghai Zhoupu Hospital, Pudong New Area. 1500 Zhouyuan Rd, \\ Zhoupu, Shanghai, 201318, P.R. China. \\ \# These authors contributed equally in this work \\ *E-mail: pancai_163s@foxmail.com
}

doi: $10.20964 / 2017.08 .61$

Received: 2 May 2017 / Accepted: 18 June 2017 / Published: 12 July 2017

This work used electrochemical impedance measurements and anodic polarisation to study the corrosion susceptibility of $\mathrm{Ti}, \mathrm{Ti}-6 \mathrm{Al}-4 \mathrm{~V}$ and $\mathrm{TZNT}$ in a buffered saline solution (PBS). The impedance characterization model was obtained under open-circuit conditions and was a double-oxide film model consisting of an inner-barrier oxide layer and a porous, outer layer. Low-pitting potentials were obtained for TZNT. The property of the outer layer depended on the presence of phosphate anions in the saline-buffered solution (SBS) and the electrode material. The typical, low resistances of the porous layers generated on TZNT with phosphate anions ranged from 10 to $70 \Omega \mathrm{cm}^{2}$. Ti, TZNT and $\mathrm{Ti}-6 \mathrm{Al}-4 \mathrm{~V}$ all displayed much higher porous layer resistances without phosphate anions.

Keywords: Titanium alloy; Bone implant; Corrosion resistance; Electrochemical impedance spectroscopy; Medical application

\section{$\underline{\text { FULL TEXT }}$}

(C) 2017 The Authors. Published by ESG (www.electrochemsci.org). This article is an open access article distributed under the terms and conditions of the Creative Commons Attribution license (http://creativecommons.org/licenses/by/4.0/). 